Monika Szafrańska

University of Agriculture in Krakow

\title{
FACTORS DETERMINING THE LEVEL OF FINANCIAL LITERACY OF ACADEMIC YOUTH
}

\begin{abstract}
The main objective of the paper is to characterize the level of financial literacy of academic youth and to identify selected socio-demographic factors that determine this level. The main source of data used for analysis and conclusions was primary information obtained from the author's own research. The research was conducted in 2018 with the PAPI method on a group of 337 respondents. The interview was conducted with young people studying at the second largest academic centre in Poland - Kraków. The study used a set of questions to assess the level of financial literacy of adults proposed by the OECD. Apart from primary sources, Polish and foreign literature on the subject was also used to achieve the goal. To analyze the data, total statistical indicators (mean, minimum, maximum) and non-parametric "chi square" test" $\left(\chi^{2}\right)$ were used. The analysis shows that students are characterized by an average level of financial literacy. The factors that significantly determined the level of students' financial literacy were gender and the field of study. A higher level of financial literacy was characteristic for men and those studying the economic faculties, which results from the curriculum contents. In order to increase the level of financial competence of students in other fields of study, curricula should be supplemented with subjects covering personal finance. The factors that did not differentiate the level of financial performance are the place of residence, the degree of study and the student's professional experience.
\end{abstract}

Key words: financial attitudes, financial behaviours, financial knowledge, university students JEL Codes: G41, G53

\section{Introduction}

In the literature on the subject, the concept of financial literacy (financial capacity) is defined differently. Z. Kozubíková defines financial literacy as the ability to understand finances ${ }^{1}$. According to $\mathrm{S}$. Huston ${ }^{2}$ this term means the ability to make informed judgments and make effective decisions regarding the use and management of money ${ }^{3}$. According to A. Lusardi and O.S. Mitchell ${ }^{4}$ financial literacy is the knowledge of basic financial concepts needed to make rational financial decisions regarding saving, investing, taking out loans and insurance. Similarly, financial literacy is defined by the

1 Z. Kozubíková: Analysis of the impact economic education on the level of financial literacy. Knowledge for Market Use 2017: people in economics - decisions, behavior and normative models, 2017, p. 932.

${ }^{2}$ S. Huston: Measuring Financial Literacy. The Journal of Consumer Affairs 44(2)/2010, p. 306-307.

${ }^{3}$ J. Rybička, A. Kozubik: Self-reflection of the university students in financial literacy. Knowledge for Market Use 2017: people in economics - decisions, behavior and normative models, 2017, p. 682.

${ }^{4}$ A. Lusardi, O. Mitchell: The economic importance of financial literacy. Theory and evidence. Journal of Economic Literature 52 (1)/2014, p. 6. 
Jump\$tart Coalition ${ }^{5}$ as the ability of an individual to use financial literacy to effectively manage financial resources. A broader definition of financial literacy is proposed by the Organization for Economic Cooperation and Development (OECD). According to this definition, financial literacy includes not only financial knowledge, but also skills, attitudes and appropriate financial behaviour necessary to make rational financial decisions ${ }^{6}$. In turn, M. Musial ${ }^{7}$ believes that financial literacy is a set of elements such as financial knowledge, skills, attitudes and behaviours together with factors influencing them, both internal (demographic, social, economic, behavioural) and external (e.g. economic, technological, etc.) factors allowing a person to effectively manage personal finances.

The lack of an adequate level of financial literacy has certain consequences. In the area of personal finance, low levels of financial literacy can lead to a choice of both inappropriate financial institutions and financial services themselves that do not match consumers' needs and financial capacities. These issues are particularly relevant in the context of better planning of the financial future (retirement, periods without work). According to A. O'Connell ${ }^{8}$ a low level of financial literacy is the cause of excessive consumption, household debt and unnecessary spending of money.

Financial education is the only way to increase citizens' financial literacy. According to M. Iwanicz-Drozdowska and A. Nowak ${ }^{9}$ the term financial education means activities aimed at disseminating knowledge and developing positive habits among citizens, leading to making the right decisions regarding management of their personal finances and effective use of financial resources now and in the future. In order for educational programs to be effective, their authors must take into account the needs and requirements of beneficiaries in this respect.

Research concerning the determination of the level of financial literacy has been undertaken in Poland for many years. Most often it concerns the determination of the general level of financial knowledge of the population ${ }^{10,11}$ or its groups ${ }^{12,13,14}$.

\footnotetext{
5 Jump\$tart Coalition: National Standards in K-12 Personal Finance Education. http://www.jumpstart.org/guide.html., 2007, p. 1 .

6 OECD INFE: International survey of adult financial literacy competencies, 2016, www.oecd.org/finance/financial-education, p. 17

${ }^{7}$ M. Musiał: Efektywność gospodarowania finansami osobistymi w Polsce [Effectiveness of personal finance management in Poland ]. Wydawnictwo Naukowe Uniwersytetu Szczecińskiego, 2018, p. 55.

8 O'Connell: Measuring the effectiveness of financial education, 2017, http://www.retirement.org.nz/files/Measuring_effectiveness_of_financial_education_OConnell_published_Apr il07, p. 2.

${ }^{9}$ M. Iwanicz-Drozdowska, A. Nowak: Rola i znaczenie edukacji finansowej. [The role and importance of financial education] [in:] Edukacja i świadomość finansowa. Doświadczenia i perspektywy [Education and financial literacy. Experiences and perspectives], Ed. M. Iwanicz-Drozdowska, Oficyna Wydawnicza SGH, Warszawa, 2011, p. 13.

${ }^{10}$ Citi Handlowy. Stan wiedzy finansowej Polaków. Raport Fundacji Kronenberga przy Citi Handlowy [The state of financial knowledge of Poles. Report of the Kronenberg Foundation at Citi Handlowy], 2009, Dom Badawczy Maison, Warszawa, p. 4.

${ }^{11}$ S. Smyczek: Financial Literacy of Consumer in the Central and Eastern Europe Countries. Zeszyty Naukowe Uniwersytetu Ekonomicznego, 303/2016, p. 24.

${ }^{12}$ P. Majewski, D. Walczak: Świadomość ubezpieczeniowa studentów w aspekcie postrzegania rynku ubezpieczeniowego [Insurance awareness of students in terms of the perception of the insurance market]. Studia Oeconomica Posnaniensia 1 (11)/2013, p. 42.
} 
However, there is a lack of detailed research to determine the level of financial literacy covering knowledge, behaviours and financial attitudes of selected social groups.

For sure one of the most important and scientifically interesting groups are students. These are usually people aged 19-30 years who start their own life, take up their first job and start managing their own financial resources. Academic youth constitute a statistically significant group of the population. In Poland, the gross enrolment rate for higher education is almost $50 \%{ }^{15}$.

Therefore, the main objective of the paper is to characterize the level of financial literacy of academic youth and to identify selected socio-demographic factors that determine this level.

\section{Methodology}

The main source of data used for analysis and conclusions was primary information obtained from the author's own research. The research was conducted in 2018 with the PAPI method on a group of 337 respondents. The interview was conducted with young people studying at the second largest academic centre in Poland - Kraków. The choice of this centre was determined by the fact that the structure of students studying at Kraków's universities by gender and place of residence corresponds to the structure of students for the whole country. The selection of the sample for the study was deliberate. Students who expressed their willingness to complete the questionnaire participated in the research.

In the academic year 2017/2018, the number of students in the analyzed academic centre amounted to 135,989 persons (excluding foreigners ${ }^{16}$ ). The following formula was used to estimate the minimum number of samples $(n)^{17}$ :

$$
n=\frac{\frac{1}{4} \cdot N}{N \cdot \frac{d^{2}}{z_{\alpha / 2}^{2}}+\frac{1}{4}}
$$

where:

$\mathrm{N}$ - population size,

$\mathrm{Z}_{\alpha / 2}^{2}-$ the value of random variable $\mathrm{Z}$ of normal standard distribution,

$\mathrm{d}$ - statistical error.

\footnotetext{
${ }^{13}$ E. Kuchciak, M. Świeszczak, K. Świeszczak, M. Marcinkowska: Edukacja finansowa i inkluzja bankowa w realizacji koncepcji silver economy [Financial education and banking inclusion in the implementation of the silver economy concept], Wydawnictwo Uniwersytetu Łódzkiego, Łódź, 2014, p.8.

${ }^{14}$ M. Musiał., B. Świecka: Analiza wiedzy i umiejętności finansowych młodego pokolenia [Analysis of the knowledge and financial skills of the young generation]. Acta Universitatis Lodziensis Folia Oeconomica 6 (326)/2016, p. 203.

${ }^{15}$ Studencka Marka. Liczba studentów w Polsce [Number of students in Poland], 2018,

https://www.studenckamarka.pl/serwis.php?s=73\&pok=1909

${ }^{16}$ Urząd Statystyczny w Krakowie: Informacje sygnalne. Szkoły wyższe w województwie małopolskim w roku akademickim 2017/2018 [Statistical Office in Krakow: Lead information. Higher education institutions in Małopolskie voivodship in the academic year 2017/2018], 2018, p. 1.

${ }^{17}$ Szreder M: Metody i techniki sondażowych badań opinii [Methods and techniques of opinion polls], PWE, Warszawa, 2004, p. 118
} 
In the studies it was assumed that the maximum statistical error of the results may amount to +/- 5\%. The necessary minimum sample size was set at 312 persons. The study covered 350 students. Following the rejection of inconsistent and incorrectly completed questionnaires, 337 forms were further analysed.

Among those who participated in the study, $58 \%$ were women and $42 \%$ were men. The structure of the sample in terms of gender corresponded to the structure of students in Małopolskie Province and in Poland in the academic year 2017/2018 ${ }^{18}$. According to the questionnaire, almost $40 \%$ of respondents worked during their studies. The dominating group in the discussed group were students of second cycle studies $(57 \%)$ and students of non-economic faculties $(67 \%)$.

The study used a set of questions to assess the level of financial literacy of adults proposed by the OECD ${ }^{19}$. The application of the OECD methodology made it possible to compare the results of the study with the results presented by other authors who also used this method. The questionnaire form consisted of four parts and contained 24 closed-ended single-choice questions. The first part was a certificate (5 questions). The following parts concerned particular components of financial literacy: basic financial knowledge (7 questions), financial behaviour (9 questions) and financial attitudes (3 questions).

Apart from primary sources, Polish and foreign literature on the subject was also used to achieve the goal. To analyze the data, total statistical indicators (mean, minimum, maximum) and non-parametric "chi square" test" $\left(\chi^{2}\right)$ were used. This test allows the assessment of the relevance of a relationship between variables when at least one of them is immeasurable. All the hypotheses were verified with a horizontal significance of $\alpha=0,05$. The results of the research were presented in a descriptive and tabular form.

\section{Determinants of the level of financial literacy}

The OECD methodology ${ }^{20}$ was used to calculate the overall indicator characterising the level of financial literacy. The target value of the index is the sum of the results obtained in the three modules forming the respondent's financial literacy: financial knowledge, financial behaviour and financial attitudes. In total, the student could obtain a minimum of 1 credit point and a maximum of 21 points.

According to the conducted research, the average result obtained by students is almost 13 points (12.8) out of 21 possible points. The lowest score achieved in the discussed group was 5 points $(1.5 \%$ of the respondents), the highest -20 points, which was achieved by $3 \%$ of the students. Most respondents received 11 points from

\footnotetext{
${ }^{18}$ Urząd Statystyczny w Krakowie: Informacje sygnalne. Szkoły wyższe w województwie małopolskim w roku akademickim 2017/2018 [Statistical Office in Krakow: Lead information. Higher education institutions in Małopolskie voivodship in the academic year 2017/2018], 2018, p. 1.

${ }^{19}$ OECD INFE: Measuring financial literacy questionnaire and guidance notes for conducting an internationally comparable survey of financial literacy, 2011, www.oecd.org/finance/financial-education, p. 10-26.

20 OECD INFE: International survey of adult financial literacy competencies, 2016, www.oecd.org/finance/financial-education, p. 85-90.
} 
the test (15\% of all respondents). The obtained results correspond to the results of other researchers ${ }^{21}$.

In order to apply the non-parametric $\chi^{2}$ test, 3 levels of financial literacy were established: low (1-7 points), medium (8-14 points) and high (15-21 points). According to the questionnaire, the majority of respondents had an average level of financial literacy $(55 \%)$. The remaining persons were characterized by a low level of financial literacy $(25 \%)$ and a high level $(20 \%)$.

Table 1. Factors determining the level of financial literacy of academic youth (non-parametric $\chi^{2}$ test)

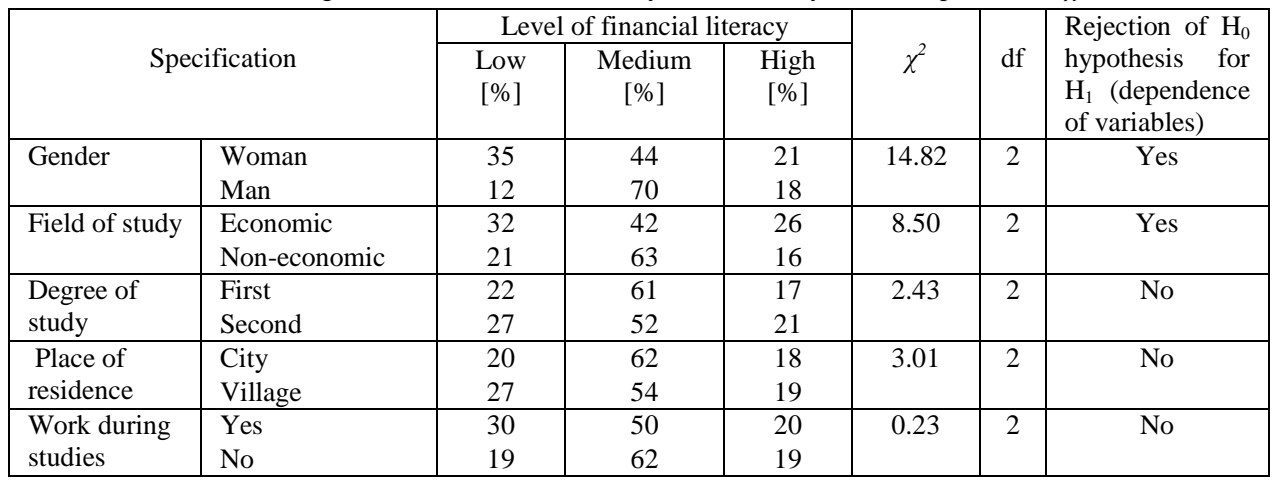

Source: author's own research.

One of the factors that significantly determined the level of financial literacy was the gender of students (Table 1). Women were characterized by a lower level of financial competence. In the case of female students, the share of people with a low level of financial literacy was $35 \%$, while in the group of students this share was $12 \%$. The results obtained are consistent with the results obtained by other authors. According to the research of M. Kubak and the team ${ }^{22}$, which conducted research on a group of 496 Slovak students, a low level of financial literacy was characteristic for every third student $(31 \%)$ and every tenth student $(10 \%)$.

Another factor differentiating the level of financial literacy was the field of study. The share of economic students with a high level of financial literacy was 10 percentage points higher than the respondents of other faculties. This is understandable, because the issues asked in the questionnaire are consistent with the program contents of these faculties. On the other hand, the share of economic students with a low level of financial literacy was as much as 11 percentage points higher than those studying non-economic faculties. The result may be related to the fact that the majority of economics students are students of lower years of first degree studies, therefore some curriculum contents concerning financial literacy may not have been presented to students yet.

21 OECD INFE: International survey of adult financial literacy competencies, 2016, www.oecd.org/finance/financial-education, p. 53.

${ }^{22}$ M. Kubak, A. Tkacova, A. Androniceanu, M. Tvaronavičiené, E. Huculova: Financial Literacy of Students in Chosen Universities - Research Platform for Regulatory Processes of Educational System in Slovakia. Finance, 1/2018, s. 180 . 
The statistical analysis also checked whether the degree of studies is a factor determining the level of financial literacy of students. As can be seen from the data presented in Table 1, this determinant does not significantly differentiate the level of financial literacy of young people. The average test score achieved by first-cycle students was 11 points, while for second-cycle students it was only 0.6 points higher. Other factors that did not determine the level of students' financial literacy were their place of residence and the student's professional experience.

In the next stage of statistical analysis, it was checked whether selected sociodemographic factors determine the results obtained by students in particular modules creating financial literacy. One of the elements creating financial literacy is basic financial knowledge. The level of financial knowledge of the respondents was assessed by means of 7 questions. These questions concerned the calculation of the interest rate, the mechanism of compound interest rate, inflation, diversification of the financial portfolio or the relationship between the amount of risk and the rate of return. The student received 1 credit for each correct answer. Respondents could obtain 0 points in this part of the test at least and 7 points at most. The average result obtained by respondents was 4.4 points. Most students answered 5 questions correctly. Every tenth person obtained the maximum score from the test, and $7 \%$ of the respondents received only 1 point.

The issue that caused the most problems to the respondents was the determination of the purchasing power of money, assuming that inflation would remain constant for a year. The correct answer to this question was given by less than $40 \%$ of the respondents. The result obtained is lower than the results presented in the literature, which shows that most people know the correct answer to this question ${ }^{23}$. The issue with the highest percentage of correct answers was the relationship between the degree of risk and the rate of return on the financial instrument. The correct answer to this question was given by $90 \%$ of the respondents.

Table 2. Factors determining the level of financial knowledge of academic youth (non-parametric $\chi^{2}$ test)

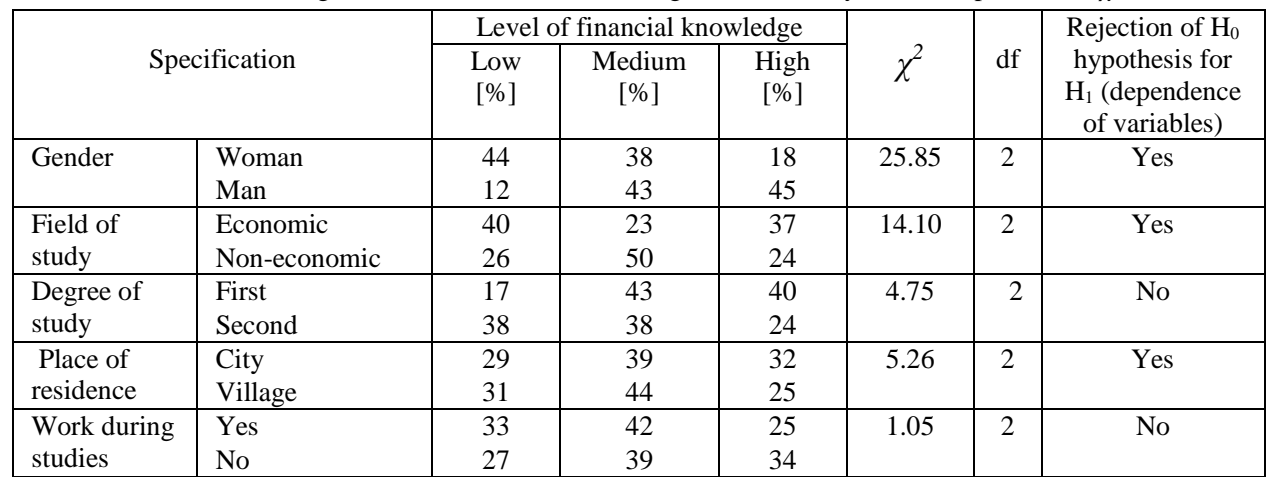

Source: author's own research.

23 OECD INFE: International survey of adult financial literacy competencies, 2016, www.oecd.org/finance/financial-education, p. 21. 
The statistical analysis (Table 2) shows that the factors that shaped the level of financial knowledge were gender, field of study and place of residence. Men were characterized by a higher level of knowledge of basic financial issues. Almost every second student had a high level of financial knowledge. Female students, on the other hand, represented mainly a low level. The results obtained are consistent with the results of the OECD studies. These questionnaires show that in 19 countries out of 30 countries that participated in the research, gender was a statistically significant factor determining the level of financial literacy ${ }^{24}$.

Similar to the case of the general financial literacy indicator, a higher level of financial literacy was observed among students of economics (37\% vs. 24\%). The inhabitants of cities were also characterized by a higher level of financial knowledge. This situation results from lower access of rural youth to financial, ICT and educational infrastructure. This phenomenon is also observed in other countries ${ }^{25}$.

The factor that did not statistically determine the level of financial knowledge of respondents was the degree of studies, although the obtained results show differences in the level of knowledge between first and second degree students (Table 2). Another determinant not influencing the level of financial knowledge of students was the professional activity of young people. Both in the group of students who worked during their studies and in the group of respondents who did not work, the percentage share of people with an average level of knowledge was the highest. The lack of influence of professional experience on the level of financial knowledge of young people was also demonstrated by S. Nidar and S. Bestari in their studies ${ }^{26}$. They studied the impact of 24 factors on the level of students' financial knowledge. One of the determinants that did not differentiate this level was the professional experience of respondents.

Another component of financial literacy is financial behaviours. Financial behaviour is the deliberate or unintentional management of personal finances during a defined period of time ${ }^{27}$. Students' financial behaviour was assessed by 9 questions. These questions concerned the degree of independence in daily financial decisionmaking, the ability to draw up a household budget, active saving, the willingness to pay bills on time, prudent shopping and setting financial targets. For each rational behaviour the students could get 1 point. The minimum result from this part was 0 points, the maximum - 9. The average score for the examined group was 5.7 points. Every twentieth respondent in this financial literacy module received only 1 point, and $3 \%$ of students correctly marked all the answers.

Most of the problems for young people were caused by the question of the ability to prepare a household budget, understood as a statement of income and expenditure within a fixed period of time. According to the research, less than $40 \%$ of students register and control their income and expenses. Most respondents have never heard of such

\footnotetext{
24 OECD INFE: International survey of adult financial literacy competencies, 2016, www.oecd.org/finance/financial-education, p. 31

${ }^{25}$ A. Lusardi, O. Mitchell: The economic importance of financial literacy. Theory and evidence. Journal of Economic Literature 52 (1)/2014, p. 20.

${ }^{26}$ Nidar S., Bestari S.: Persoanl Financial Literacy Among University Students (Case Study at Padjadjaran University Students, bandung, Indonesia). World Journal of Socal Sciences 2(4)/2012, p. 169.

${ }^{27}$ M. Musiał: Efektywność gospodarowania finansami osobistymi w Polsce [Efficiency of personal finance management in Poland], Wydawnictwo Naukowe Uniwersytetu Szczecińskiego, 2018, p. 54.
} 
a practice. Awareness of the budget available to the young consumer should be the basis for rational planning of expenses by the student. Most correct answers were found in the question on timely payment of bills. The presented research shows that one in five students pays their bills late.

Table 3. Factors determining financial behaviours of academic youth (non-parametric $\chi^{2}$ test)

\begin{tabular}{|c|c|c|c|c|c|c|c|}
\hline \multirow{2}{*}{\multicolumn{2}{|c|}{ Specification }} & \multicolumn{3}{|c|}{ Financial behaviours } & \multirow{3}{*}{$\frac{\chi^{2}}{3.46}$} & \multirow{3}{*}{$\frac{\mathrm{df}}{2}$} & \multirow{3}{*}{$\begin{array}{c}\begin{array}{c}\text { Rejection of } \mathrm{H}_{0} \\
\text { hypothesis for }\end{array} \\
\mathrm{H}_{1} \text { (dependence } \\
\text { of variables) }\end{array}$} \\
\hline & & \multirow{2}{*}{$\begin{array}{c}\begin{array}{c}\text { Low } \\
\text { result } \\
{[\%]}\end{array} \\
30 \\
39\end{array}$} & \multirow{2}{*}{$\begin{array}{c}\begin{array}{c}\text { Medium } \\
\text { result } \\
{[\%]}\end{array} \\
35 \\
38\end{array}$} & \multirow{2}{*}{$\begin{array}{c}\begin{array}{c}\text { High } \\
\text { result } \\
{[\%]}\end{array} \\
35 \\
23\end{array}$} & & & \\
\hline Gender & $\begin{array}{l}\text { Woman } \\
\text { Man }\end{array}$ & & & & & & \\
\hline Field of study & $\begin{array}{l}\text { Economic } \\
\text { Non-economic }\end{array}$ & $\begin{array}{l}42 \\
29\end{array}$ & $\begin{array}{l}26 \\
42\end{array}$ & $\begin{array}{l}32 \\
29\end{array}$ & 11.71 & 2 & Yes \\
\hline $\begin{array}{l}\text { Degree of } \\
\text { study }\end{array}$ & $\begin{array}{l}\text { First } \\
\text { Second }\end{array}$ & $\begin{array}{l}40 \\
30\end{array}$ & $\begin{array}{l}30 \\
40\end{array}$ & $\begin{array}{l}30 \\
30\end{array}$ & 1.54 & 2 & No \\
\hline $\begin{array}{l}\text { Place of } \\
\text { residence }\end{array}$ & $\begin{array}{l}\text { City } \\
\text { Village }\end{array}$ & $\begin{array}{l}36 \\
29\end{array}$ & $\begin{array}{l}39 \\
29\end{array}$ & $\begin{array}{l}25 \\
42\end{array}$ & 20.82 & 2 & Yes \\
\hline $\begin{array}{l}\text { Work during } \\
\text { studies }\end{array}$ & $\begin{array}{l}\text { Yes } \\
\text { No }\end{array}$ & $\begin{array}{l}36 \\
31\end{array}$ & $\begin{array}{l}41 \\
31 \\
\end{array}$ & $\begin{array}{l}23 \\
38 \\
\end{array}$ & 10.16 & 2 & Yes \\
\hline
\end{tabular}

Source: author's own research.

The conducted research indicated that the factors that influence the rationality of students' financial behaviour are: the field of study, place of residence and student's professional activity (Table 3). A higher degree of rationality of financial behavior was observed among students of non-economic faculties, where the share of persons with medium and high scores was $71 \%$, while the share of respondents studying economic faculties was lower by 13 percentage points. Higher results achieved by non-economic students are related to the fact that a significant proportion of them work during their studies, which translates into a higher percentage of those who make daily financial decisions on their own and bear the consequences of such decisions. Students from cities also received higher scores in this part of the test. The factors that did not differentiate financial behaviour were the degree of study and gender. The results obtained are consistent with the results presented by other authors. From E. Rindali's and L. Todesco's research ${ }^{28}$ of 1,635 young people, results showed that women and men do not differ in terms of (questionnaire-measured) elements of financial literacy.

Another component of financial literacy is financial attitudes. As A. Gąsiorowska points out ${ }^{29}$, people do not treat money equally, they differ significantly in their attitude to money, or in the place they attribute to it in their lives. Attitudes towards money may influence many financial behaviours of a person, such as efforts to obtain money, saving, taking loans and credit, rationality of spending money or style of shopping. The questionnaire included three questions to assess respondents' attitudes towards money and financial planning. The claims made in the questionnaire were "I tend to live for today and let tomorrow take care of itself", "I find it more satisfying to spend money

${ }^{28}$ E. Rindali, L. Todesco: Financial Literacy and Money Attitudes. Do Boys and Girls Really Differ? A Study among Italian Predolesescentes. Italian Journal of Sociology of Education 2/2012, p. 143.

${ }^{29}$ A. Gąsiorowska: Psychologiczne znaczenie pieniędzy [The psychological significance of money], PWN, Warszawa, 2014, p. 53. 
than to save it for the long term", "Money is there to be spent" ${ }^{30}$. In order to assess attitudes, the five-point Likert scale was used, where 1 meant that the student fully agrees with the statement, 5 - completely disagrees. The content of the questions concerned attitudes in the short term, so if the respondent did not agree with the statement (answers 4 and 5) it meant that he or she had such an attitude in the long term (attitudes desirable from the point of view of rationality of consumer behaviour). The points marked by the respondents were summed up and the value obtained was divided by 3 . The minimum number of points in this module was 1 and the maximum number was 5 . The average score obtained by the group in question was 1.7 points.

Table 4. Factors determining financial attitudes of academic youth (non-parametric $\chi^{2}$ test)

\begin{tabular}{|c|c|c|c|c|c|c|c|}
\hline & & & ancial attitu & & & & Rejection of $\mathrm{H}_{0}$ \\
\hline Spe & ication & Low & Medium & High & $\chi^{2}$ & & hypothesis for \\
\hline Gender & $\begin{array}{l}\text { Woman } \\
\text { Man }\end{array}$ & $\begin{array}{l}51 \\
47 \\
\end{array}$ & $\begin{array}{l}31 \\
37\end{array}$ & $\begin{array}{l}18 \\
16 \\
\end{array}$ & 0.75 & 2 & No \\
\hline Field of study & $\begin{array}{l}\text { Economic } \\
\text { Non-economic }\end{array}$ & $\begin{array}{l}44 \\
52 \\
\end{array}$ & $\begin{array}{l}28 \\
36 \\
\end{array}$ & $\begin{array}{l}28 \\
12 \\
\end{array}$ & 8.99 & 2 & Yes \\
\hline $\begin{array}{l}\text { Degree of } \\
\text { study }\end{array}$ & $\begin{array}{l}\text { First } \\
\text { Second }\end{array}$ & $\begin{array}{l}52 \\
48 \\
\end{array}$ & $\begin{array}{l}30 \\
33 \\
\end{array}$ & $\begin{array}{l}18 \\
19 \\
\end{array}$ & 3.27 & 2 & No \\
\hline $\begin{array}{l}\text { Place of } \\
\text { residence }\end{array}$ & $\begin{array}{l}\text { City } \\
\text { Village }\end{array}$ & $\begin{array}{l}46 \\
62\end{array}$ & $\begin{array}{l}33 \\
22\end{array}$ & $\begin{array}{l}21 \\
16\end{array}$ & 6.77 & 2 & Yes \\
\hline $\begin{array}{l}\text { Work during } \\
\text { studies }\end{array}$ & $\begin{array}{l}\text { Yes } \\
\text { No }\end{array}$ & $\begin{array}{l}50 \\
48\end{array}$ & $\begin{array}{l}31 \\
37\end{array}$ & $\begin{array}{l}19 \\
15\end{array}$ & 1.02 & 2 & No \\
\hline
\end{tabular}

Source: author's own research.

In order to use the non-parametric $\chi^{2}$ test, three groups of respondents were distinguished: the first group, i.e. persons with a low score (1.0-2.3 points), the second group - medium score (2.4-3.7 points) and the third group - persons with the highest score - high score (3.8-5.0 points). The research carried out shows (Table 4) that the factors determining financial attitudes are the field of study and the place of residence. In the group of economics students, the share of people with high scores in comparison to respondents of non-economics was higher by 16 percentage points. Significant difference in results is caused by the implemented study curriculum.

Higher results were also achieved by students from rural areas. The results obtained are consistent with the results of other authors, which show that there are differences in attitudes towards money between the inhabitants of towns and villages. The rural population is dominated by a traditional approach to work and consumption ${ }^{31}$. According to the U. Swadźba's research ${ }^{32}$, urban youth have a materialistic approach to

${ }^{30}$ OECD INFE: International survey of adult financial literacy competencies, 2016, www.oecd.org/finance/financial-education, p. 50.

${ }^{31}$ G. Wąsowicz-Kiryło: Postawy wobec pieniądza. Pomiar-struktura-determinanty [Attitudes towards money. Measurement-structure-determinants]. Difin, Warszawa, 2013, p. 199.

${ }^{32}$ U. Swadźba: Oszczędzać czy wydawać? Postawy studentów wobec pieniędzy [Save or spend? Students' attitudes towards money]. Prace Naukowe Uniwersytetu Ekonomicznego we Wrocławiu 501/2017, p. 129. 
life to a much greater extent than their peers in rural areas and more often assess people through the perspective of money.

The statistical analysis shows that financial attitudes of students are not determined by their gender, degree and professional activity. The difference in average results between women and men was 0.1 points. A low score was obtained by $51 \%$ of women and $47 \%$ of men. $50 \%$ of those who worked and $48 \%$ of those who did not work also received a low score. Taking into account the degree of study, the difference between first-cycle and masters students with low scores was only 4 p.p.

\section{Summary}

The conducted research made it possible to assess the level of financial literacy of academic youth, as well as to identify selected factors that differentiate this level. The analysis shows that students are characterized by an average level of financial literacy, which may indicate low effectiveness of actions in the field of financial education carried out both at previous levels of education (preuniversity) and at the academic level. In order to increase the effectiveness of the implemented educational activities, attention should be paid to the selection of appropriate tools and methods of teaching. In the process of financial education, teachers and lecturers should use both traditional methods and methods specific to new technologies.

The factor that significantly determined the level of students' financial literacy and differentiated the individual elements creating financial literacy was the field of study. A higher level of financial literacy was characteristic for those studying the economic faculties, which results from the curriculum contents. In order to increase the level of financial competence of students in other fields of study, curricula should be supplemented with subjects covering personal finance. It should be remembered that appropriate education of young people will prepare them in the future for active and conscious participation in the financial markets.

Urban youth were characterized by a higher level of financial literacy. Differences in the level of financial literacy of young people in relation to their place of residence (village/city) result from the characteristics of these environments (availability of financial, educational and commercial infrastructure). Students from cities were also characterized by a higher level of financial knowledge. In the case of financial behaviour and attitudes, rural norms have achieved higher results. In this case, the differences are due to different customs and standards that apply in these environments. These differences should be taken into account when designing educational activities in the field of financial education dedicated to rural youth and city dwellers.

Taking into account the gender of students, it can be stated that it is a factor significantly determining the level of financial knowledge, which at the same time differentiates the level of financial literacy of young people. Men were characterized by a higher level of knowledge. No differences in financial behaviour and attitudes between students were observed.

The factors that did not differentiate the level of financial performance are the degree of study and the student's professional experience. The degree of study also does not affect any of the components that create financial literacy. In the case of the student's professional activity, a higher share of rational financial behaviours was observed among those who work.

In order to design appropriate educational activities for students, as well as to follow the dynamics of changes in the level of financial literacy of academic youth, there is a need to continue research in this area in subsequent periods. In future analyses, in addition to sociodemographic factors, economic determinants should also be taken into account, which may also differentiate the financial functioning of individuals. 


\section{Literature}

Citi Handlowy. Stan wiedzy finansowej Polaków. Raport Fundacji Kronenberga przy Citi Handlowy, Dom Badawczy Maison, Warszawa, 2009

Gąsiorowska A.: Psychologiczne znaczenie pieniędzy, PWN, Warszawa, 2014

Huston S.: Measuring Financial Literacy. The Journal of Consumer Affairs 44/2/2010, p. 296-316

Iwanicz-Drozdowska M., Nowak A.: Rola i znaczenie edukacji finansowej. [The role and importance of financial education] [In:] Edukacja i świadomość finansowa. Doświadczenia i perspektywy [Education and financial literacy. Experiences and perspectives]. Ed. M. Iwanicz-Drozdowska, Oficyna Wydawnicza SGH, Warszawa, 2011

Jump\$tart Coalition.: National Standards in K-12 Personal Finance Education. http://www.jumpstart.org/guide.html., 2007

Kozubíková Z:: Analysis of the impact economic education on the level of financial literacy. Knowledge for Market Use 2017: people in economics - decisions, behavior and normative models, 2017, p. 932-938.

Kubak M., Tkacova A., Androniceanu A., Tvaronavičiené M., Huculova E.: Financial Literacy of Students in Chosen Universities - Research Platform for Regulatory Processes of Educational System in Slovakia, Finance, 1/2018, p. 175-190.

Kuchciak E., Świeszczak M., Świeszczak K., Marcinkowska M.: Edukacja finansowa i inkluzja bankowa $w$ realizacji koncepcji silver economy [Financial education and banking inclusion in the implementation of the silver economy concept], Wydawnictwo Uniwersytetu Łódzkiego, Łódź, 2014

Lusardi A., Mitchell O.: The economic importance of financial literacy. Theory and evidence. Journal of Economic Literature 52 (1)/2014, s. 5-44, doi: 10.1257/jel.52.1.5.

Majewski P., Walczak D.: Świadomość ubezpieczeniowa studentów w aspekcie postrzegania rynku ubezpieczeniowego [Insurance awareness of students in terms of the perception of the insurance market], Studia Oeconomica Posnaniensia 1 (11)/2013, p. 42-50.

Musiał M.: Efektywność gospodarowania finansami osobistymi w Polsce [Effectiveness of personal finance management in Poland], Wydawnictwo Naukowe Uniwersytetu Szczecińskiego, Szczecin, 2018

Musiał M., Świecka B.: Analiza wiedzy i umiejętności finansowych młodego pokolenia [Analysis of the knowledge and financial skills of the young generation], Acta Universitatis Lodziensis Folia Oeconomica 6 (326)/2016, s. 203-2016

Nidar S., Bestari S.: Persoanl Financial Literacy Among University Students (Case Study at Padjadjaran University Students, bandung, Indonesia). World Journal of Social Sciences 2(4)/2012 O'Connell A.: Measuring the effectiveness of financial education, 2017, http://www.retirement.org.nz/files/Measuring_effectiveness_of_financial_education_OConnell_pu blished_April07, access: 15.12.2018.

OECD INFE.: Measuring financial literacy questionnaire and guidance notes for conducting an internationally comparable survey of financial literacy, 2011, www.oecd.org/finance/financialeducation, access: 15.12.2018.

OECD INFE.: International survey of adult financial literacy competencies, 2016, www.oecd.org/finance/financial-education, access: 15.12.2018.

Rindali E., Todesco L.: Financial Literacy and Money Attitudes. Do Boys and Girls Really Differ? A Study among Italian Predolesescentes. Italian Journal of Sociology of Education 2/2012

Rybička J., Kozubik A.: Self-reflection of the university students in financial literacy. Knowledge for Market Use 2017: people in economics - decisions, behavior and normative models, 2017, p. $682-693$.

Smyczek S.: Financial Literacy of Consumer in the Central and Eastern Europe Countries, Zeszyty Naukowe Uniwersytetu Ekonomicznego, 303/2016, s. 24-35. 
Studencka Marka: Liczba studentów w Polsce [Number of students in Poland], 2018, https://www.studenckamarka.pl/serwis.php?s=73\&pok=1909, access: 24.03.2019.

Swadźba U.: Oszczędzać czy wydawać? Postawy studentów wobec pieniędzy [Save or spend? Students' attitudes towards money]. Prace Naukowe Uniwersytetu Ekonomicznego we Wrocławiu 501/2017, s.119-130, doi 10.15611/pn.2017.501.11

Szreder M.: Metody i techniki sondażowych badań opinii [Methods and techniques of opinion polls], PWE, Warszawa, 2004

Urząd Statystyczny w Krakowie.: Informacje sygnalne. Szkoły wyższe w województwie małopolskim w roku akademickim 2017/2018 [Lead information. Higher education institutions in Malopolskie voivodship in the academic year 2017/2018], 2018, https://www.krakow.stat.gov.pl, access: 15.12 .2018 .

Wąsowicz-Kiryło G.: Postawy wobec pieniądza. Pomiar-struktura-determinanty [Attitudes towards money. Measurement-structure-determinants]. Difin, Warszawa, 2013

\section{Czynniki determinujące poziom świadomości finansowej młodzieży akademickiej}

\section{Streszczenie}

Celem pracy jest charakterystyka poziomu świadomości finansowej młodzieży akademickiej oraz identyfikacja wybranych czynników o charakterze socjo-demograficznym, które determinują ten poziom. Zasadniczym źródłem danych wykorzystanych do analizy i wnioskowania były informacje pierwotne uzyskane $\mathrm{z}$ badań własnych. Badania przeprowadzono w 2018 roku, metodą PAPI na grupie 337 respondentów. Wywiad został przeprowadzony z młodzieżą studiującą w drugim pod względem wielkości ośrodku akademickim w Polsce - Krakowie. W badaniach wykorzystano zestaw pytań umożliwiający ocenę poziomu świadomości finansowej osób dorosłych zaproponowany przez OECD. Poza źródłami pierwotnymi wykorzystano również źródła wtórne. Do analizy danych zastosowano sumaryczne wskaźniki statystyczne (średnia, minimum, maksimum) oraz nieparametryczny test „chi kwadrat” $\left(\chi^{2}\right)$. Jak wynika z przeprowadzonej analizy, studenci cechują się średnim poziomem świadomości finansowej. Czynnikami, który istotnie determinują poziom świadomości finansowej studentów są płeć oraz kierunek studiów. Wyższym poziomem świadomości finansowej charakteryzowali się mężczyźni oraz osoby studiujace na kierunkach ekonomicznych, co wynika $\mathrm{z}$ realizowanych treści programowych. $\mathrm{W}$ celu wzrostu poziomu kompetencji finansowych osób studiujących na pozostałych kierunkach, programy studiów powinny zostać uzupełnione o przedmioty obejmujące kwestie finansów osobistych. Czynnikami, które nie różnicowały poziomu świadmości finansowej są miejsce zamieszkania, stopień studiów oraz doświadczenie zawodowe studenta.

Słowa kluczowe: postawy finansowe, zachowania finansowe, wiedza finansowa, studenci JEL Codes: G41, G53

Information about author:

Dr inż. Monika Szafrańska

Uniwersytet Rolniczy im. H. Kołłątaja w Krakowie

Katedra Zarządzania i Ekonomii Przedsiębiorstw

Al. Mickiewicza 21, 31-120 Kraków

e-mail: monika.szafranska@urk.edu.pl

ORCID: 0000-0002-4948-7636 